\title{
House of Risk (HoR) Analysis Application for Supply Chain Risk Management (SCRM) in Micro Small and Medium - Sized Enterprises (MSMSs)
}

\author{
Dyah Lintang Trenggonowati $1^{*}$, Yusraini Muharni ${ }^{1}$, Asep Ridwan ${ }^{1}$, Alya Mustika \\ Wardhani $^{1}$
}

${ }^{1}$ Department of Industrial Engineering, University of Sultan Ageng Tirtayasa, Banten, Indonesia *Corresponding author. Email: dyahlintang@untirta.ac.id

\begin{abstract}
Tofu has characteristic that is easily damaged so it needs proper handling from raw materials to shipping, otherwise, the tofu will have low quality and easy to break so that the shelf life becomes shorter. Besides that, in terms of quantity, the lower production upstream will reduce the availability of downstream products. The uncertain information flow from upstream to downstream and vice versa, will exacerbate some of the potential risks throughout the supply chain. This research focuses on evaluation along the supply chain with the information flow from upstream to downstream and vice versa. Identification of data was taken by conducting in-depth interviews with Micro Small Medium Enterprise (MSME) owners. This study focuses on Supply Chain Risk (SCR) identification with complete information along the supply chain activity using Supply Chain Operations Reference (SCOR), mitigation strategies by applying House of Risk (HOR) analysis in Supply Chain Risk Management (SCRM), along with decision-making models and risk information. This study takes place at XYZ. The result of the study, it is known that there are 20 risk events and 16 risk agents have been identified along with 11 proactive actions as preventive measures proposed to the XYZ MSME.
\end{abstract}

\section{Keywords: HOR Analysis, SCRM, MSMEs, Tofu Handling}

\section{INTRODUCTION}

Resilient supply chain network design and risk deployment analysis, supplier selection and order allocation, facility location and reliable inventory management, coordination, contract pricing and risk sharing are key research concepts in Supply Chain Risk (SCR) mitigation. Supply chain is a connection of several companies that collaborate to produce and distribute product to the end customer [1]. In its practice, supply chain has a broad scope from suppliers to final consumers which will cause risks that interrupt the supply chain activity. Risk is an uncertainty about an event which causes a loss [2]. Loss is a major impact for the company [3]. Risks can affect negatively to company. It's necessary to have Supply Chain Risk Management (SCRM) so that the risk is not bothering the supply chain activity in company. SCRM is a process of identifying risk, analyzing risk, evaluating risk, and mitigating risk [4].

$\mathrm{XYZ}$ is one of Micro Small Medium Enterprise (MSME) which produces various types of tofu. XYZ is a MSME that located in Banten Province, Indonesia. White tofu is one of the products that XYZ produce and is the raw material to produce other types of tofu. MSMEs turnover per month is around twenty million rupiah. Based on the interview with the owner, it is known that XYZ has problems related to their supply chain activity. The problems faced by the company are insufficient stock of ordered soybean raw materials from supplier when the time it should be pick up, delay in the arrival of firewood by the firewood supplier, the quality of soybean raw material is not good enough, machine breakdown, power outage, return of damaged tofu, and many more that should be identified. 


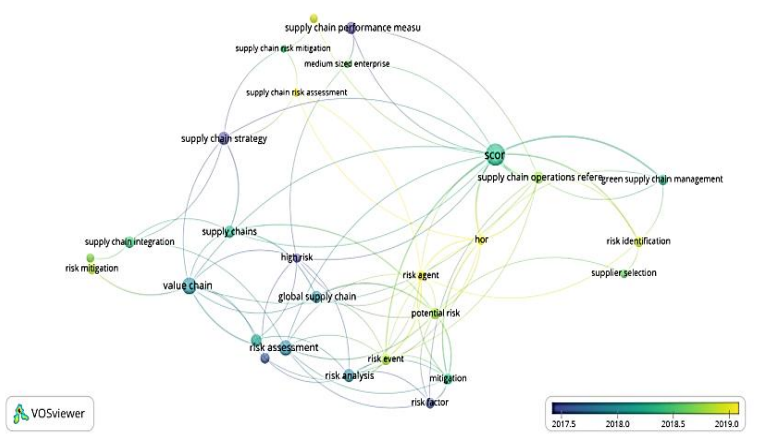

Figure 1. Output VOSviewer.

Tofu has characteristic that is easily damaged so it needs proper handling from raw materials to deliver, otherwise, the tofu will be low quality and easily damaged so that the shelf life will be shorter. In addition, in terms of quantity, the lower production upstream will reduce the availability of downstream products. The potential risks throughout the supply chain can be exacerbated by the uncertain flow of information from upstream to downstream and vice versa. This research focuses on mapping risks along the supply chain with the information flow from upstream to downstream and vice versa. Identification of data was taken by conducting indepth interviews with MSME owners.

From Output VOSviewer Figure 1 above, it is presenting a systematic literature and comprehensive analysis for SCR mitigation by the decision-making model. Overall, there are \pm 1000 published research articles from 2017 until 2021 in journals with the Academic Journal Guide quality rating were collected and a further \pm 197 articles were selected as the main literature. Several research clusters were formed including, (i) identifying the main research concepts in SCR mitigation [5], (ii) studying the relationship between risk measures, risk attitudes of decision makers, and modeling techniques used [6], (iii) studying the relationship between mitigation actions and its modeling techniques [7], and (iv) identify the SCR, mitigation strategies, and decision-making models most discussed by scholars working on SCR mitigation [8]. The results show that demand, disruption, and supply risks have received the most attention, while the involvement of information, reputation, credit, and exchange rate risks in SCRM has received the least attention. This study focuses on identifying SCRs with complete information along the supply chain, mitigation strategies by applying House of Risk (HOR) analysis in SCRM, along with decision-making models and risk information. The framework of risk mitigation is shown in Figure 2 below.

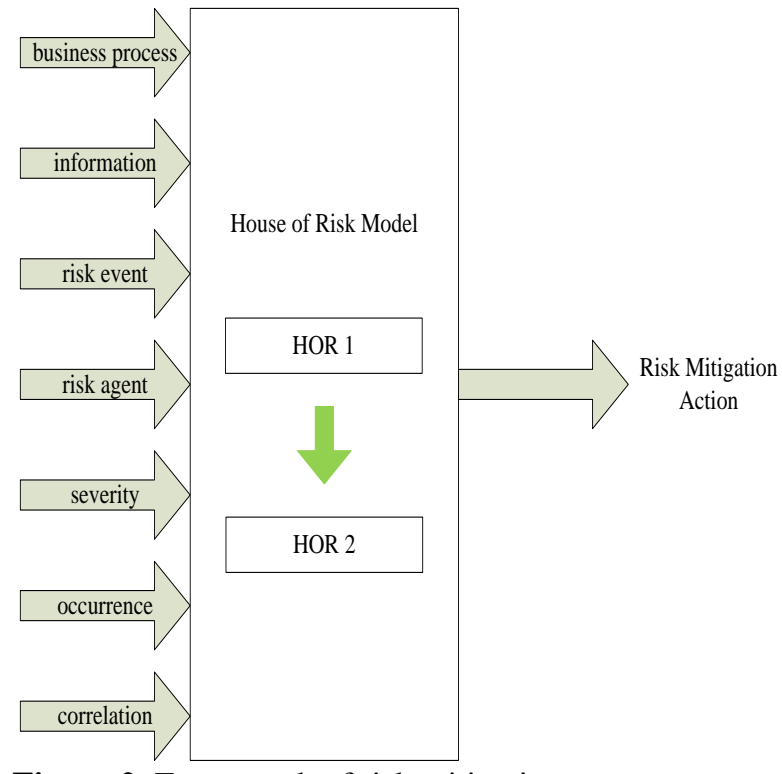

Figure 2. Framework of risk mitigation.

Currently, XYZ does not have a proper supply chain risk management yet. Therefore, it is necessary to identify further risks regarding the risks that have not been identified as well as supply chain risk mitigation actions in XYZ to prevent the causes of risk so as to minimize the impact of risks that have the potential to interrupt the supply chain activities of the company. The right supply chain risk management strategy can minimize risks to maintain the continuity of supply chain activity [9]. This research aims to identify risk event and risk agent that interrupt the supply chain activity in XYZ, determine which risk agents are prioritized to be mitigated, and determine mitigation action to be implemented in $\mathrm{XYZ}$. To identify risk event and risk agent, it is necessary to find out the activities that occur in the supply chain using Supply Chain Operation Reference (SCOR) model. Based on supply chain activity mapping, identify risk event of each process. And then, analyzed the risks by assess risk event for severity, identify risk agent as the cause of risk event, and assess risk agent for occurrence. Also, risk event and risk agent are assessed for correlation. Based on severity, occurrence, and correlation, determine Aggregate Risk Potential (ARP) and rank it. After that, determine the prioritized risk agent by its ARP using Pareto diagram, this step called risk evaluation. Risk identification, risk analysis, and risk evaluation is conducted using HOR 1 . To determine mitigation action, it is necessary to identify the proactive action as mitigation of each prioritized proactive action, assessed correlation between risk agent and risk event, and assessed proactive action for degree of difficulty. This step called risk mitigation. Risk mitigation conducted using HOR 2. 
The output from this study is mitigation action that helps to reduce the effect of supply chain risk in MSME using HOR analysis.

\section{METHODS}

The research was conducted in XYZ and used primary data consist of interview data, observations, and questionnaires. The research project has adopted the Supply Chain Operations Reference (SCOR) model, House of Risk (HOR) method, and Pareto diagram to identify and mitigate the supply chain risk. The details of the research design can be seen in Figure 3 below.

\subsection{Supply Chain Operations Reference (SCOR)}

To identify and mitigate the supply chain risk, supply chain activities should be mapped using Supply Chain Operations Reference (SCOR). The purpose of this models is to find out what activities occur in the supply chain [10]. SCOR mapped the supply chain activity based on five core processes named plan, source, make, deliver and return as follows [11]:

a. Plan, is a process that balancing demand and supply as a whole, which aims to develop optimal delivery, production and supply requirements.

b. Source, focuses on the process of procuring raw materials including the process of purchasing goods and services that aim to meet planned or actual demand.

c. Make, is the process of transforming material into a final product to meet the planned actual demand.

d. Deliver, is a process to fulfill customer demand, including purchasing, transportation and distribution.

e. Return, is an activity of returning products to the company by customer for various reasons.

\subsection{House of Risk (HOR)}

The result of SCOR model is an input for House of Risk (HOR) method. House of Risk (HOR) is a method used to manage risk proactively, where risk agents identified as the cause of risk events can be managed by giving a priority order based on the impact that may be caused and effective proactive steps can also be determined to reduce the possibility of the risk occurs [12]. HOR is divided into two phases, there are HOR 1 which is called the identification phase and HOR 2 which is called the handling phase.

\subsubsection{House of Risk (HOR) 1}

HOR 1 or identification phase is used to identify risks and determine the priority level of risk agents that must be given as a preventive action. HOR phase 1 is used to determine which risk agents are prioritized for proactive action [12]. The risk management process using the HOR 1 method is the process of risk identification, risk analysis and risk evaluation. The following are the stages of HOR 1 [13].

a. Identify risk event

Based on the result of SCOR model, that is supply chain activity mapping, identify risk event for each activity. The identified risk events are risks that occur or have the potential to occur in supply chain activities. Risk event identification can be done by analyzing what, where, how, and why the risk occurs [14].

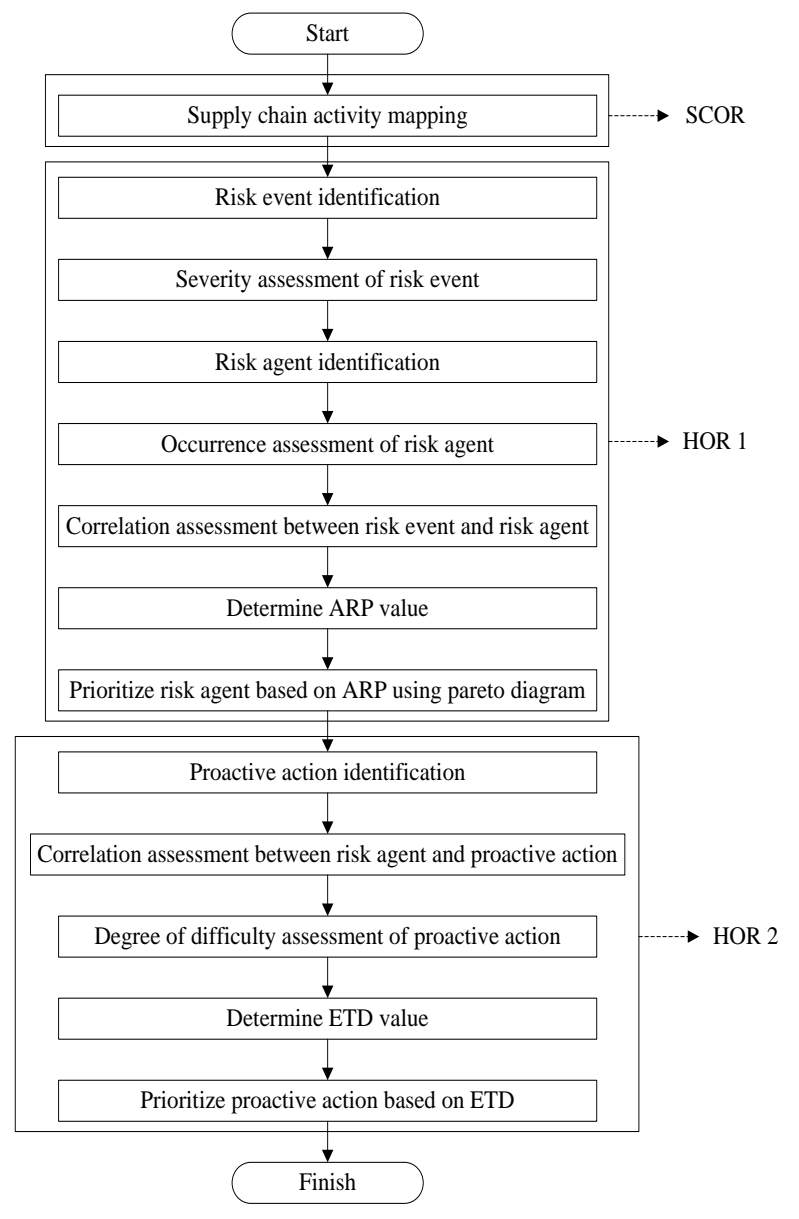

Figure 3. Research design.

b. Assessing severity of risk event

Severity is an assessment of how severe the impact is if a risk event occurs [15]. Severity assessment is done by giving a score starts from a scale of 1 where the impact is the lightest to 10 is the most dangerous impact. Severity assessment can be done by estimating the impact of risk event.

c. Identify risk agent as the cause of risk event 
Risk agent is identified as the cause of risk event. Risk agent can be identified by each risk event.

d. Assessing occurrence of risk agent

Occurrence is the probability that the risk will occur and refers to the frequency of the risk occurs [14]. Occurrence assessment is done by giving a score starts from a scale of 1 where the incidence rate is the lowest to 10 where the incidence rate is the highest. Occurrence assessment is conducted by estimating the probability of risk agent.

e. Assessing correlation between risk event and risk agent

Correlation shows how strong the relationship is between two or more variables. In this stage, correlation is assessed between risk event and risk agent. Correlation level assessment is conducted by assigning a value from a scale of $0,1,3$ and 9 where 0 indicates no correlation, 1 indicates weak correlation, 3 indicates moderate correlation, and 9 indicates strong correlation [16].

f. Calculate the ARP value

ARP is used to determine the sequence of risk agents that needs to be mitigating [13]. The following is the formula of ARP.

$$
\mathrm{ARP}_{\mathrm{j}}=\mathrm{O}_{\mathrm{j}} \sum \mathrm{S}_{\mathrm{I}} \mathrm{R}_{\mathrm{ij}}
$$

$\mathrm{ARP}_{\mathrm{j}}=$ Aggregate Risk Potential

$\mathrm{O}_{\mathrm{j}} \quad=$ Occurrence of risk agent

$\mathrm{S}_{\mathrm{i}} \quad$ = Severity of risk event

$\mathrm{R}_{\mathrm{ij}} \quad=$ Correlation between risk event and risk agent

$\mathrm{i} \quad=$ Risk event number

$\mathrm{j} \quad=$ Risk agent number

g. Rank risk agents

Risk agent is ranked based on ARP values in descending order from largest to lowest value.

h. Prioritize the risk agents

Risk agents is prioritized using Pareto diagram.

\subsubsection{House of Risk (HOR) 2}

HOR 2 is the handling phase where the identified risks are mitigated. HOR 2 is used to determine the proactive action to be taken by considering differences effectively such as the involvement of sources and the level of difficulty in its implementation [17]. The risk management process using the HOR 2 method is the process of mitigation. Risk mitigation is the stage where reducing or eliminating the possibility of certain risks or their impacts. The following are the stages of HOR 2 [13].

a. Determine prioritized risk agent
Prioritized risk agent is the result of risk evaluation stage in HOR 1. Prioritized risk agent is the risk agent that should be mitigate.

b. Identify proactive action

Proactive action is an action to prevent or reduce prioritized risk agent to minimize the impact of risks that have the potential to interrupt the company's supply chain activity.

c. Assessing correlation between risk agent and proactive action

In this stage, correlation is assessed between risk agent and proactive action. Correlation level assessment is conducted by assigning a value from a scale of $0,1,3$ and 9 [16].

d. Assessing degree of difficulty of proactive action Degree of difficulty is a scale for determining the level of difficulty that reflects the costs and other resources required to perform a proactive action [18]. Degree of difficulty assessment is conducted by assigning a value from a scale of 3,4 , and 5 where 3 indicates mitigation actions are not too difficult to implement and the costs incurred are considered quite affordable, 4 indicates mitigation is quite difficult to implement and the costs incurred are considered quite high, and 5 indicates mitigation actions are difficult to implement and the costs incurred are considered high [18].

e. Calculate the Total Effectiveness (TE) value Total effectiveness is uses to know how effective the proactive action to mitigate risk agent.

$$
\mathrm{TE}_{\mathrm{k}}=\sum_{\mathrm{j}} \mathrm{ARP}_{\mathrm{j}} \mathrm{E}_{\mathrm{jk}}
$$

$\mathrm{TE}_{\mathrm{k}}=$ Total effectiveness of proactive action

$\mathrm{ARP}_{\mathrm{j}}=$ Aggregate risk potential of risk agent

$\mathrm{E}_{\mathrm{jk}} \quad=$ Correlation between proactive action and risk agent

$\mathrm{j} \quad=$ Risk agent number

$\mathrm{k}=$ Proactive action number

f. Calculate ETD value Effectiveness to Difficulty (ETD) value is an output from House of Risk (HOR) 2. The ETD value considers the level of difficulty based on effective and efficient resources and costs [16].

$$
\mathrm{ETD}_{\mathrm{k}}=\frac{T E_{\mathrm{k}}}{\mathrm{D}_{\mathrm{k}}}
$$

$\mathrm{ETD}_{\mathrm{k}}=$ Effectiveness to Difficulty of proactive action

$\mathrm{TE}_{\mathrm{k}}=$ Total Effectiveness of proactive action

$\mathrm{D}_{\mathrm{k}} \quad=$ Degree of Difficulty of proactive action

$\mathrm{k}=$ Proactive action number 
The ARP is calculated with the HOR 1 matrix as shown in Table 1 on the $80 / 20$ principle that around $80 \%$ of risk problems caused by $20 \%$ [16]. In this research, Pareto diagram is

Table 1. House of risk (HOR) 1 matrix.

\begin{tabular}{|c|c|c|c|c|c|c|c|c|c|}
\hline \multirow{2}{*}{ Business Process } & \multirow{2}{*}{ Risk Event (Ei) } & \multicolumn{7}{|c|}{ Risk Agent (j) } & \multirow[t]{2}{*}{ Severity } \\
\hline & & $A_{1}$ & $\mathbf{A}_{2}$ & $\mathbf{A}_{3}$ & $\mathbf{A}_{4}$ & $A_{5}$ & $\mathbf{A}_{6}$ & $A_{7}$ & \\
\hline \multirow{2}{*}{ Plan } & $E_{1}$ & $\mathrm{R}_{11}$ & $\mathrm{R}_{12}$ & $\mathrm{R}_{13}$ & & & & & $\mathrm{~S}_{1}$ \\
\hline & $E_{2}$ & & & & & & & & $\mathrm{~S}_{2}$ \\
\hline \multirow{2}{*}{ Source } & $E_{3}$ & $\mathrm{R}_{21}$ & $\mathrm{R}_{22}$ & & & & & & $\mathrm{~S}_{3}$ \\
\hline & $\mathrm{E}_{4}$ & & & & & & & & $\mathrm{~S}_{4}$ \\
\hline \multirow{2}{*}{ Make } & $E_{5}$ & $\mathrm{R}_{31}$ & & & & & & & $\mathrm{~S}_{5}$ \\
\hline & $E_{6}$ & & & & & & & & $\mathrm{~S}_{6}$ \\
\hline Deliver & $E_{7}$ & & & & & & & & $\mathrm{~S}_{7}$ \\
\hline Return & $\mathrm{E}_{8}$ & & & & & & & & $\mathrm{~S}_{8}$ \\
\hline Occurrence & & $\mathrm{O}_{1}$ & $\mathrm{O}_{2}$ & $\mathrm{O}_{3}$ & $\mathrm{O}_{4}$ & $\mathrm{O}_{5}$ & $\mathrm{O}_{6}$ & $\mathrm{O}_{7}$ & \\
\hline ARP & & $\mathrm{ARP}_{1}$ & $\mathrm{ARP}_{2}$ & $\mathrm{ARP}_{3}$ & $\mathrm{ARP}_{4}$ & $\mathrm{ARP}_{5}$ & $\mathrm{ARP}_{6}$ & $\mathrm{ARP}_{7}$ & \\
\hline \multicolumn{2}{|l|}{ Priority Rank } & & & & & & & & \\
\hline $\begin{array}{l}\mathrm{A}_{1}, \mathrm{~A}_{2}, \mathrm{~A}_{3} \ldots \mathrm{A}_{\mathrm{n}} \\
\mathrm{E}_{1}, \mathrm{E}_{2}, \mathrm{E}_{3} \ldots \mathrm{E}_{\mathrm{n}} \\
\mathrm{O}_{1}, \mathrm{O}_{2}, \mathrm{O}_{3}, \ldots \mathrm{O}_{\mathrm{n}} \\
\mathrm{R}_{11}, \mathrm{R}_{12}, \mathrm{R}_{13}, \ldots \mathrm{R}_{\mathrm{ij}} \\
\mathrm{S}_{1}, \mathrm{~S}_{2}, \mathrm{~S}_{3}, \ldots \mathrm{S}_{\mathrm{n}} \\
\mathrm{ARP}_{1}, \mathrm{ARP}_{2}, \mathrm{ARP}_{3}, \mathrm{ARP}_{\mathrm{n}}\end{array}$ & \multicolumn{9}{|c|}{$\begin{array}{l}=\text { Risk agent } \\
=\text { Risk event } \\
=\text { Occurrence of risk agent } \\
=\text { Correlation between risk event and risk agent } \\
=\text { Severity of risk event } \\
=\text { Aggregate Risk Potential of risk agent }\end{array}$} \\
\hline
\end{tabular}

The ETD can be calculated with the HOR 2 matrix as shown in Table 2. used for determine which risk agent should be prioritized first based on ARP in HOR 1. The formula used for calculating the ARP percentage used to describe the Pareto

Table 2. House of risk (HOR) 2 matrix.

\begin{tabular}{|c|c|c|c|c|c|c|c|}
\hline \multirow{2}{*}{\multicolumn{2}{|c|}{ To be Treated Risk Agent $\left(A_{j}\right)$}} & \multicolumn{5}{|c|}{ Proactive Action $\left(\mathbf{P A}_{\mathbf{k}}\right)$} & \multirow{2}{*}{$\begin{array}{c}\text { Aggregate Risk Poten- } \\
\text { tials (ARP) }\end{array}$} \\
\hline & & $\mathrm{PA}_{1}$ & $\mathbf{P A}_{2}$ & $\mathbf{P A}_{3}$ & $\mathrm{PA}_{4}$ & PA5 & \\
\hline \multicolumn{2}{|l|}{$\mathrm{A}_{1}$} & $\mathrm{E}_{11}$ & $\mathrm{E}_{12}$ & & & & $\mathrm{ARP}_{1}$ \\
\hline \multicolumn{2}{|l|}{$\mathrm{A}_{2}$} & $E_{21}$ & & & & & $\mathrm{ARP}_{2}$ \\
\hline \multicolumn{2}{|l|}{$A_{3}$} & & & & & & $\mathrm{ARP}_{3}$ \\
\hline \multicolumn{2}{|l|}{$\mathrm{A}_{4}$} & & & & & & $\mathrm{ARP}_{4}$ \\
\hline \multicolumn{2}{|l|}{ Total Effectiveness } & $\mathrm{TE}_{1}$ & $\mathrm{TE}_{2}$ & $\mathrm{TE}_{3}$ & $\mathrm{TE}_{4}$ & $\mathrm{TE}_{5}$ & \\
\hline \multicolumn{2}{|l|}{ Degree of Difficulty } & $\mathrm{D}_{1}$ & $\mathrm{D}_{2}$ & $\mathrm{D}_{3}$ & $\mathrm{D}_{4}$ & $\mathrm{D}_{5}$ & \\
\hline \multicolumn{2}{|l|}{ Effectiveness to Difficulty } & ETD $_{1}$ & $\mathrm{ETD}_{2}$ & $\mathrm{ETD}_{3}$ & $\mathrm{ETD}_{4}$ & $\mathrm{ETD}_{5}$ & \\
\hline \multicolumn{2}{|l|}{ Rank of Priority } & $\mathrm{R}_{1}$ & $\mathrm{R}_{2}$ & $\mathrm{R}_{3}$ & $\mathrm{R}_{4}$ & $\mathrm{R}_{5}$ & \\
\hline $\begin{array}{l}\mathrm{PA}_{1}, \mathrm{PA}_{2}, \mathrm{PA}_{3} \ldots \mathrm{PA}_{\mathrm{n}} \\
\mathrm{A}_{1}, \mathrm{~A}_{2}, \mathrm{~A}_{3} \ldots \mathrm{A}_{\mathrm{n}} \\
\mathrm{E}_{11}, \mathrm{E}_{12}, \mathrm{E}_{13} \ldots \mathrm{E}_{\mathrm{nm}} \\
\mathrm{ARP}_{1}, \mathrm{ARP}_{2}, \mathrm{ARP}_{3}, \ldots \mathrm{ARP}_{\mathrm{n}} \\
\mathrm{TE}_{1}, \mathrm{TE}_{2}, \mathrm{TE}_{3}, \ldots \mathrm{TE}_{\mathrm{n}} \\
\mathrm{D}_{1}, \mathrm{D}_{2}, \mathrm{D}_{3}, \ldots \mathrm{D}_{\mathrm{n}} \\
\mathrm{ETD}_{1}, \mathrm{ETD}_{2}, \mathrm{ETD}_{3}, \ldots \mathrm{ETD}_{\mathrm{n}} \\
\mathrm{R}_{1}, \mathrm{R}_{2}, \mathrm{R}_{3}, \ldots \mathrm{R}_{\mathrm{n}}\end{array}$ & \multicolumn{6}{|c|}{$\begin{array}{l}=\text { Proactive action } \\
=\text { Prioritized risk agent } \\
=\text { Correlation between risk agent and proactive action } \\
=\text { Aggregrate risk potential of risk agent } \\
=\text { Total effectiveness of proactive action } \\
=\text { Degree of Difficulty of proactive action } \\
=\text { Effectiveness to Difficulty of proactive action } \\
=\text { Rank of proactive action }\end{array}$} & \\
\hline
\end{tabular}

\subsection{Pareto Diagram}

Pareto diagram is a diagram that displays a sequence of data based on the highest to lowest values used to determine the main problem or priority [17]. The highest ranking indicates a priority problem that must be handled immediately and the lowest rank indicates a problem that is not urgent to be handled. The Pareto chart is based diagram is as follows.

a. ARP percentage

$$
\% \text { ARP }=\frac{\text { ARP }}{\text { Total ARP }} \times 100 \%
$$

b. Cumulative ARP percentage

$\% \mathrm{Cum}=$ Cum total $\%$ ARP before + currt $\% \mathrm{~A}$ 


\section{RESULTS AND DISCUSSION}

Table 3. Supply chain activity mapping.

\begin{tabular}{|l|l|}
\hline Main Process & \multicolumn{1}{|c|}{ Sub Process } \\
\hline \multirow{4}{*}{ Plan } & Production planning \\
\cline { 2 - 2 } & Raw material inventory control \\
\hline \multirow{5}{*}{ Source } & Choosing raw material supplier \\
\cline { 2 - 2 } & Scheduling raw material pick up \\
\cline { 2 - 2 } & Scheduling raw material delivery \\
\cline { 2 - 2 } & Raw material pick up \\
\cline { 2 - 2 } & Raw material delivery \\
\cline { 2 - 2 } & Raw material inspection \\
\hline \multirow{3}{*}{ Make } & Production process of tofu \\
\cline { 2 - 2 } & Finished product inspection \\
\hline Deliver & Delivering product to customer \\
\hline \multirow{2}{*}{ Return } & $\begin{array}{l}\text { Return reject product from cus- } \\
\text { tomer }\end{array}$ \\
\hline
\end{tabular}

The first step of supply chain risk mitigation is mapping the supply chain activities to five core processes using SCOR model. The supply chain activity map in XYZ is shown in Table 3. From the table 3 is known that there are 12 supply chain activities in XYZ. Risk events are identified based on each activity of supply chain. This stage called risk identification. Risk identification is a stage in the risk mitigation process by finding or collecting risks that occur and have the potential to occur in supply chain activities [13].

In this research, risk identification is conducted by interviewing and brainstorming with the owner of XYZ. Identified risk events are assessed for severity. This assessment is conducted by filling out a questionnaire. The questionnaire filled out by expert judgments that are owner and workers. The severity questionnaire was distributed to 30 respondents. The result of risk event and its severity are shown in Table 4 .

Table 4. Risk event.

\begin{tabular}{|c|c|c|c|c|}
\hline $\begin{array}{l}\text { Main Pro- } \\
\text { cess }\end{array}$ & Sub Process & Risk Event & Code & Severity \\
\hline \multirow[t]{3}{*}{ Plan } & Production planning & Sudden change in production plan & $\mathrm{E} 1$ & 7.4 \\
\hline & \multirow{2}{*}{ Raw material inventory control } & $\begin{array}{l}\text { Inaccurate planned of raw material } \\
\text { quantity to be ordered }\end{array}$ & E2 & 7.5 \\
\hline & & $\begin{array}{l}\text { Gap between recorded and availa- } \\
\text { ble stock }\end{array}$ & E3 & 6.3 \\
\hline \multirow[t]{7}{*}{ Source } & Choosing raw material supplier & Error in choosing a supplier & E4 & 6.5 \\
\hline & Scheduling raw material pick up & $\begin{array}{l}\text { Delay in soybean raw materials } \\
\text { pick up }\end{array}$ & E5 & 7.5 \\
\hline & Scheduling raw material delivery & $\begin{array}{l}\text { Delay in firewood raw materials de- } \\
\text { livery }\end{array}$ & E6 & 7.5 \\
\hline & Raw material pick up & $\begin{array}{l}\text { Insufficient supply of ordered soy- } \\
\text { bean raw materials }\end{array}$ & E7 & 8.2 \\
\hline & Raw material delivery & $\begin{array}{l}\text { Different type of received firewood } \\
\text { to what was ordered }\end{array}$ & E8 & 6.9 \\
\hline & \multirow[t]{2}{*}{ Raw material inspection } & $\begin{array}{l}\text { Incorrect quantity of received raw } \\
\text { material }\end{array}$ & E9 & 7.9 \\
\hline & & Damaged raw material or reject & E10 & 8.7 \\
\hline \multirow[t]{8}{*}{ Make } & \multirow{6}{*}{ Production process of tofu } & Machine breakdown & E11 & 9.1 \\
\hline & & Work accident & $\mathrm{E} 12$ & 8.1 \\
\hline & & $\begin{array}{l}\text { An error occurred in tofu making } \\
\text { process }\end{array}$ & E13 & 8.7 \\
\hline & & Disruption of electrical supply & E14 & 9.2 \\
\hline & & Disruption of water supply & E15 & 9.1 \\
\hline & & Delay in tofu production process & E16 & 7.3 \\
\hline & \multirow[b]{2}{*}{ Finished product inspection } & Damaged tofu or reject & E17 & 6.9 \\
\hline & & $\begin{array}{l}\text { Quantity of tofu production has not } \\
\text { met customer demand }\end{array}$ & E18 & 8.3 \\
\hline Deliver & Delivering product to customer & Delay in delivery to customer & E19 & 7.4 \\
\hline Return & Return reject product from customer & Defective or damaged tofu & E20 & 7.4 \\
\hline
\end{tabular}


The next stage is risk analysis. The risk analysis stage includes consideration of the impact of the risk, the causes of the risk, the probability for the risk to occur and determine the Aggregate Risk Potential (ARP) [18]. From Table 4 above, it is known that there are 20 risk events are identified in XYZ and its severity. The severity value comes from averaged result of the questionnaire. Each risk event can cause disruption of supply chain activity in the company. Based on the risk event, risk agent is identified as the cause of risk event. Several risk events can be caused by a risk agent and a risk event can be caused by several risk agents [13]. Identified risk agents are assessed for occurrence. This assessment is conducted by filling out a questionnaire. The questionnaire filled out by expert judgments that are owner and workers. The occurrence questionnaire was distributed to 30 respondents. The result of risk agent and its occurrence are shown in Table 5.

Table 5. Risk agent.

\begin{tabular}{|c|l|c|}
\hline Code & \multicolumn{1}{|c|}{ Risk Agent } & Occurrence \\
\hline A1 & $\begin{array}{l}\text { Sudden change in demand } \\
\text { by customer }\end{array}$ & 8.3 \\
\hline A2 & $\begin{array}{l}\text { Error in checking remaining } \\
\text { stock }\end{array}$ & 5.9 \\
\hline A3 & $\begin{array}{l}\text { The supplier does not meet } \\
\text { the company's criteria }\end{array}$ & 6.4 \\
\hline A4 & No evaluation for supplier & 6.3 \\
\hline A5 & $\begin{array}{l}\text { There is obstacle on the } \\
\text { way }\end{array}$ & 7.5 \\
\hline A6 & $\begin{array}{l}\text { There is obstacle from fire- } \\
\text { wood suppliers }\end{array}$ & 7.6 \\
\hline A7 & $\begin{array}{l}\text { Lack of coordination with } \\
\text { soybean suppliers }\end{array}$ & 8 \\
\hline A8 & $\begin{array}{l}\text { Miss communication with } \\
\text { firewood suppliers }\end{array}$ & 7.2 \\
\hline A9 & $\begin{array}{l}\text { Lack of accuracy from the } \\
\text { supplier }\end{array}$ & 8.5 \\
\hline A10 & Lack of maintenance & 7.6 \\
\hline A11 & No SOP & 6.7 \\
\hline A12 & $\begin{array}{l}\text { Lack of workers concern to } \\
\text { HSE }\end{array}$ & 8.1 \\
\hline A13 & $\begin{array}{l}\text { Lack of accuracy when } \\
\text { making the product }\end{array}$ \\
\hline A14 & $\begin{array}{l}\text { Power outage from national } \\
\text { electricity company }\end{array}$ \\
\hline A15 & Lack of human resources \\
\hline A16 & $\begin{array}{l}\text { Lack of accuracy when in- } \\
\text { specting product }\end{array}$ & 7.9 \\
\hline
\end{tabular}

From Table is known that there are 16 risk agent are identified as the cause of risk events that occurs in XYZ and its occurrence. The occurrence value comes from averaged result of the questionnaire. From Table 8 and Table 9 above, it is known the severity of risk event of the risk agent. The risk agent is mapped by severity and occurrence using a probability impact matrix model. This mapping aims to see the condition and the classification of the risk [17]. Figure 4 below is the position of the prioritize risk agent mapped in the risk map.

\begin{tabular}{|c|c|c|c|c|c|c|}
\hline \multirow{3}{*}{\multicolumn{2}{|c|}{ Occurrence }} & \multicolumn{5}{|c|}{ Severity } \\
\hline & & \multirow{3}{*}{$\begin{array}{c}1 \\
\text { Very } \\
\text { Low } \\
\end{array}$} & \multirow{3}{*}{$\frac{2}{\text { Low }}$} & \multirow{3}{*}{$\begin{array}{c}3 \\
\text { Mod- } \\
\text { erate }\end{array}$} & \multirow{3}{*}{$\begin{array}{c}4 \\
\text { High }\end{array}$} & \multirow{3}{*}{$\begin{array}{c}5 \\
\text { Very } \\
\text { High } \\
\text { A9 }\end{array}$} \\
\hline & & & & & & \\
\hline 5 & $\begin{array}{l}\text { Very } \\
\text { High }\end{array}$ & & & & & \\
\hline 4 & High & & & & $\begin{array}{l}\text { A1, } \\
\text { A5, } \\
\text { A6, } \\
A 7, \\
\text { A8, } \\
\text { A12, } \\
\text { A15, } \\
\text { A16 }\end{array}$ & $\begin{array}{l}\text { A10, } \\
\text { A11, } \\
\text { A13, } \\
\text { A14 }\end{array}$ \\
\hline 3 & $\begin{array}{l}\text { Moder- } \\
\text { ate }\end{array}$ & & & $\begin{array}{c}\mathrm{A} 2, \\
\mathrm{~A} 3, \mathrm{~A} 4\end{array}$ & & \\
\hline 2 & Low & & & & & \\
\hline 1 & $\begin{array}{l}\text { Very } \\
\text { Low }\end{array}$ & & & & & \\
\hline
\end{tabular}

Figure 4. Risk map.

From Figure 4 above, it is known that most of risk agent is on the high position. Both risk event and risk agent are assessed for correlation. This assessment is conducted by filling out a questionnaire. For more than one respondent, the determination of the correlation value is conducted by taking the value of mode [13].

The result of correlation between risk event and risk agent is shown in Table 6. From the table is known each correlation between risk event and risk agent. The correlation value comes from the mode of the questionnaire result. Mode is value that appears frequently. Severity, occurrence, and correlation are the input for Aggregate Risk Potential (ARP). ARP is calculated using the House of Risk (HOR) 1 matrix. 
Table 6. Correlation between risk event and risk agent

\begin{tabular}{|c|c|c|c|c|}
\hline Risk Event & Code & Risk Agent & Code & Correlation \\
\hline Sudden change in production plan & E1 & \multirow{2}{*}{$\begin{array}{l}\text { Sudden change in demand by } \\
\text { customer }\end{array}$} & \multirow[b]{2}{*}{ A1 } & 9 \\
\hline $\begin{array}{l}\text { Inaccurate planned of raw material quantity } \\
\text { to be ordered }\end{array}$ & E2 & & & 3 \\
\hline Gap between recorded and available stock & E3 & $\begin{array}{l}\text { Error in checking remaining } \\
\text { stock }\end{array}$ & A2 & 3 \\
\hline \multirow{2}{*}{ Error in choosing a supplier } & \multirow{2}{*}{ E4 } & $\begin{array}{l}\text { The supplier does not meet the } \\
\text { company's criteria }\end{array}$ & A3 & 9 \\
\hline & & No evaluation for supplier & A4 & 3 \\
\hline Delay in soybean raw materials pick up & E5 & There is obstacle on the way & A5 & 9 \\
\hline Delay in firewood raw materials delivery & E6 & $\begin{array}{l}\text { There is obstacle from firewood } \\
\text { suppliers }\end{array}$ & A6 & 9 \\
\hline $\begin{array}{l}\text { Insufficient supply of ordered soybean raw } \\
\text { materials }\end{array}$ & E7 & $\begin{array}{l}\text { Lack of coordination with soy- } \\
\text { bean suppliers }\end{array}$ & A7 & 9 \\
\hline $\begin{array}{l}\text { Different type of received firewood to what } \\
\text { was ordered }\end{array}$ & E8 & $\begin{array}{l}\text { Miss communication with fire- } \\
\text { wood suppliers }\end{array}$ & A8 & 3 \\
\hline Incorrect quantity of received raw material & E9 & \multirow{2}{*}{$\begin{array}{l}\text { Lack of accuracy from the sup- } \\
\text { plier }\end{array}$} & \multirow{2}{*}{ A9 } & 9 \\
\hline Damaged raw material or reject & E10 & & & 9 \\
\hline \multirow{2}{*}{ Machine breakdown } & \multirow{2}{*}{ E11 } & Lack of maintenance & A10 & 9 \\
\hline & & No SOP & A11 & 3 \\
\hline Work accident & E12 & $\begin{array}{l}\text { Lack of workers concern to } \\
\text { HSE }\end{array}$ & A12 & 1 \\
\hline An error occurred in tofu making process & E13 & $\begin{array}{l}\text { Lack of accuracy when making } \\
\text { the product }\end{array}$ & A13 & 9 \\
\hline Disruption of electrical supply & E14 & \multirow{2}{*}{$\begin{array}{l}\text { Power outage from national } \\
\text { electricity company }\end{array}$} & \multirow{2}{*}{ A14 } & 9 \\
\hline Disruption of water supply & E15 & & & 9 \\
\hline Delay in tofu production process & E16 & Lack of human resources & A15 & 3 \\
\hline Damaged tofu or reject & E17 & $\begin{array}{l}\text { Lack of accuracy when making } \\
\text { the product }\end{array}$ & A13 & 3 \\
\hline $\begin{array}{l}\text { Quantity of tofu production has not met cus- } \\
\text { tomer demand }\end{array}$ & E18 & Lack of human resources & A15 & 9 \\
\hline Delay in delivery to customer & E19 & There is obstacle on the way & A5 & 3 \\
\hline Defective or damaged tofu & E20 & $\begin{array}{l}\text { Lack of accuracy when inspect- } \\
\text { ing product }\end{array}$ & A16 & 1 \\
\hline
\end{tabular}

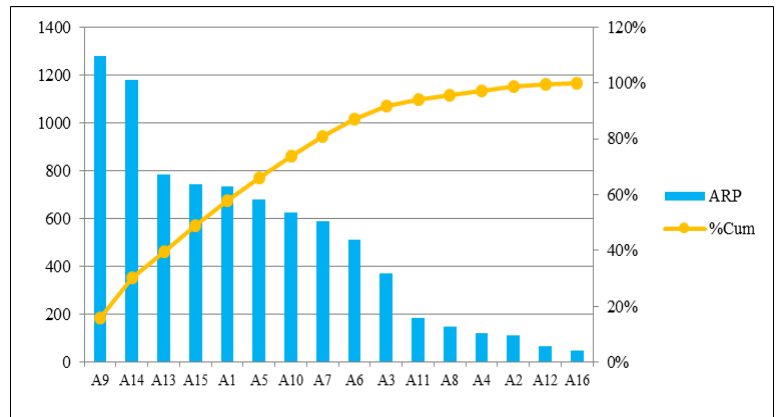

Figure 5. Pareto diagram.
The result of House of Risk (HOR) 1 is shown in Table 7 below. Based on Table 7, it is known ARP value of each risk agent and its ranking. After risk identification and risk analysis conducted, the next step is risk evaluation. The risk evaluation stage is the stage of determine prioritize risk agent for mitigation based on the ARP value [19]. 
Table 7. House of Risk (HOR) 1.

\begin{tabular}{|c|c|c|c|c|c|c|c|c|c|c|}
\hline \multirow{2}{*}{$\begin{array}{l}\text { Business } \\
\text { Process }\end{array}$} & \multirow{2}{*}{$\begin{array}{c}\text { Risk } \\
\text { Event } \\
\text { (Ei) }\end{array}$} & \multicolumn{8}{|c|}{ Risk Agent (j) } & \multirow[t]{2}{*}{$\begin{array}{l}\text { Severity } \\
\text { (Si) }\end{array}$} \\
\hline & & A1 & $\mathrm{A} 2$ & A3 & A4 & A5 & A6 & $\ldots$ & A16 & \\
\hline \multirow{3}{*}{ Plan } & E1 & 9 & & & & & & & & 7.4 \\
\hline & E2 & 3 & & & & & & & & 7.5 \\
\hline & E3 & & 3 & & & & & & & 6.3 \\
\hline \multirow{7}{*}{ Source } & E4 & & & 9 & 3 & & & & & 6.5 \\
\hline & E5 & & & & & 9 & & & & 7.5 \\
\hline & E6 & & & & & & 9 & & & 7.5 \\
\hline & E7 & & & & & & & & & 8.2 \\
\hline & E8 & & & & & & & & & 6.9 \\
\hline & E9 & & & & & & & & & 7.9 \\
\hline & E10 & & & & & & & & & 8.7 \\
\hline \multirow{8}{*}{ Make } & E11 & & & & & & & & & 9.1 \\
\hline & E12 & & & & & & & & & 8.1 \\
\hline & E13 & & & & & & & & & 8.7 \\
\hline & E14 & & & & & & & & & 9.2 \\
\hline & E15 & & & & & & & & & 9.1 \\
\hline & E16 & & & & & & & & & 7.3 \\
\hline & E17 & & & & & & & & & 6.9 \\
\hline & E18 & & & & & & & & & 8.3 \\
\hline Deliver & E19 & & & & & 3 & & & & 7.4 \\
\hline Return & E20 & & & & & & & & 1 & 7.4 \\
\hline \multicolumn{2}{|c|}{ Occurrence } & 8.3 & 5.9 & 6.4 & 6.3 & 7.5 & 7.6 & $\ldots$ & 6.5 & \\
\hline \multicolumn{2}{|c|}{ ARP } & 735.5 & 111.2 & 369.7 & 121.5 & 679.1 & 512.3 & $\ldots$ & 48.2 & \\
\hline \multicolumn{2}{|c|}{ Priority Rank } & 5 & 14 & 10 & 13 & 6 & 9 & & 16 & \\
\hline
\end{tabular}

Table 8. Pareto diagram calculation.

\begin{tabular}{|l|l|c|c|c|c|c|}
\hline Code & \multicolumn{1}{|c|}{ Risk Agent } & ARP & Rank & \%ARP & \%Cum & Category \\
\hline A9 & Lack of accuracy from the supplier & 1279.5 & 1 & 15.6 & 15.6 & 30.1 \\
\hline A14 & Power outage from national electricity company & 1181.1 & 2 & 14.4 & 39.7 \\
\hline A13 & Lack of accuracy when making the product & 785.2 & 3 & 9.6 & 4.1 & 48.8 \\
\hline A15 & Lack of human resources & 743.9 & 4 & 9.1 \\
(Primary \\
A1 & Sudden change in demand by customer & 735.5 & 5 & 9.0 & 57.8 \\
\hline A5 & There is obstacle on the way & 679.1 & 6 & 8.3 & 66.1 \\
\hline A10 & Lack of maintenance & 624.8 & 7 & 7.6 & 73.7 \\
\hline A7 & Lack of coordination with soybean suppliers & 589.1 & 8 & 7.2 & 80.9 & \\
\hline A6 & There is obstacle from firewood suppliers & 512.3 & 9 & 6.3 & 87.2 & \\
\hline A3 & The supplier does not meet the company's criteria & 369.7 & 10 & 4.5 & 91.7 \\
\hline A11 & No SOP & 183.5 & 11 & 2.2 & 93.9 \\
\hline A8 & Miss communication with firewood suppliers & 148.9 & 12 & 1.8 & 95.8 \\
\hline A4 & No evaluation for supplier & 121.5 & 13 & 1.5 & 97.3 \\
\hline A2 & Error in checking remaining stock & 111.2 & 14 & 1.4 & 98.6 \\
\hline A12 & Lack of workers concern to HSE & 65.5 & 15 & 0.8 & 99.4 \\
\hline A16 & Lack of accuracy when inspecting product & 48.2 & 16 & 0.6 & 100 \\
Priority)
\end{tabular}


Table 9. Prioritize risk agent.

\begin{tabular}{|c|l|}
\hline Code & \multicolumn{1}{c|}{ Risk Agent } \\
\hline A9 & Lack of accuracy from the supplier \\
\hline A14 & $\begin{array}{l}\text { Power outage from national electricity com- } \\
\text { pany }\end{array}$ \\
\hline A13 & Lack of accuracy when making the product \\
\hline A15 & Lack of human resources \\
\hline A1 & Sudden change in demand by customer \\
\hline A5 & There is obstacle on the way \\
\hline A10 & Lack of maintenance \\
\hline A7 & Lack of coordination with soybean suppliers \\
\hline
\end{tabular}

The risk agent that handled first is the risk agent with the biggest ARP value to the smallest ARP value and its selected based on Pareto analysis [13]. The risk evaluation stage used a Pareto diagram. The calculation for Pareto diagram is shown in Table 8. The calculation in the table above is an input to make a Pareto diagram for the ARP as shown in Figure 5. From the Figure 5 is known the prioritized risk agent that should be mitigated first. Based on the results of Table 8 and Figure 1, it can be seen that there are two categories for risk agents, called category A and category B. Category A is the primary priority and category $\mathrm{B}$ is the secondary priority. The category given based on 80/20 called Pareto principle. Therefore, the risk agents that are included in category A are a combination of risk agents which have a cumulative value of up to $80 \%$, while the remaining $20 \%$ are included in category B. Risk agents that are included in category A must be mitigate because they are included in the primary priority. The prioritize risk agents that should be mitigate is shown in Table 9.
Table 10. Proactive action.

\begin{tabular}{|c|l|}
\hline Code & \multicolumn{1}{|c|}{ Proactive Action } \\
\hline PA1 & Give a warning to the supplier \\
\hline PA2 & Make a contract with related parties \\
\hline PA3 & Purchasing a generator \\
\hline PA4 & Hold a training for the workers \\
\hline PA5 & Direct controlling to the workers \\
\hline PA6 & Labor recruitment \\
\hline PA7 & Addition working hours \\
\hline PA8 & Maintain customer relationship \\
\hline PA9 & Make a minimum order time rule \\
\hline PA10 & Create an efficient delivery schedule \\
\hline PA11 & Create a routine schedule for maintenance \\
\hline
\end{tabular}

Based on prioritize risk agent, its needed to identify proactive action as a mitigation action. This stage is called as risk mitigation stage. The risk mitigation stage is the stage of determining mitigation actions to reduce prioritized risk agents [20]. Proactive action identified by brainstorming with the owner of XYZ. Proactive action for each risk agent is shown in Table 10.

From the table 8 , it is known there are 11 proactive actions to prevent or reduce prioritized risk agent. A proactive action can mitigate several risk agents. Risk agent and proactive are assessed for correlation. This assessment is conducted by filling out a questionnaire. The result of correlation between risk agent and proactive action is shown in Table 11.

Table 11. Correlation between risk agent and proactive action.

\begin{tabular}{|c|c|c|c|c|}
\hline Risk Agent & Code & Proactive Action & Code & Correlation \\
\hline \multirow{2}{*}{ Lack of accuracy from the supplier } & \multirow{2}{*}{ A9 } & Give a warning to the supplier & PA1 & 3 \\
\hline & & Make a contract with related parties & PA2 & 9 \\
\hline $\begin{array}{l}\text { Power outage from national elec- } \\
\text { tricity company }\end{array}$ & A14 & Purchasing a generator & PA3 & 9 \\
\hline \multirow{2}{*}{$\begin{array}{l}\text { Lack of accuracy when making the } \\
\text { product }\end{array}$} & \multirow{2}{*}{ A13 } & Hold a training for the workers & PA4 & 9 \\
\hline & & Direct controlling to the workers & PA5 & 9 \\
\hline \multirow{2}{*}{ Lack of human resources } & \multirow{2}{*}{ A15 } & Labor recruitment & PA6 & 3 \\
\hline & & Addition working hours & PA7 & 9 \\
\hline \multirow{2}{*}{$\begin{array}{l}\text { Sudden change in demand by } \\
\text { customer }\end{array}$} & \multirow{2}{*}{ A1 } & Maintain customer relationship & PA8 & 3 \\
\hline & & Make a minimum order time rule & PA9 & 9 \\
\hline There is obstacle on the way & A5 & Create an efficient delivery schedule & PA10 & 3 \\
\hline Lack of maintenance & A10 & $\begin{array}{l}\text { Create a routine schedule for } \\
\text { maintenance }\end{array}$ & PA11 & 9 \\
\hline $\begin{array}{l}\text { Lack of coordination with soybean } \\
\text { suppliers }\end{array}$ & A7 & Make a contract with related parties & PA2 & 9 \\
\hline
\end{tabular}


From Table 11 above, it is known how much proactive action can affect the risk agent. After that, the proactive action is assessed for degree of difficulty. This assessment is conducted by filling out a questionnaire. The result of degree of difficulty of proactive action is shown in Table 12. From the table, it is known degree of difficulty of each proactive action. The degree of difficulty value comes from the mode of the questionnaire result.

Table 12. Degree of difficulty of proactive action.

\begin{tabular}{|c|l|c|}
\hline Code & \multicolumn{1}{|c|}{ Proactive Action } & $\begin{array}{c}\text { Degree } \\
\text { of diffi- } \\
\text { culty }\end{array}$ \\
\hline PA1 & Give a warning to the supplier & 3.8 \\
\hline PA2 & $\begin{array}{l}\text { Make a contract with related } \\
\text { parties }\end{array}$ & 3.3 \\
\hline PA3 & Purchasing a generator & 4.6 \\
\hline PA4 & Hold a training for the workers & 4 \\
\hline PA5 & $\begin{array}{l}\text { Direct controlling to the work- } \\
\text { ers }\end{array}$ & 3 \\
\hline PA6 & $\begin{array}{l}\text { Labor recruitment } \\
\text { PA7 }\end{array}$ Addition working hours & 4.6 \\
\hline PA8 & $\begin{array}{l}\text { Maintain customer relation- } \\
\text { ship }\end{array}$ & 3.6 \\
\hline PA9 & $\begin{array}{l}\text { Make a minimum order time } \\
\text { rule }\end{array}$ & 3.3 \\
\hline PA10 & $\begin{array}{l}\text { Create an efficient delivery } \\
\text { schedule }\end{array}$ & 3.4 \\
\hline PA11 & $\begin{array}{l}\text { Create a routine schedule for } \\
\text { maintenance }\end{array}$ & 3.8 \\
\hline
\end{tabular}

Mode is value that appears frequently. ARP value, correlation, and degree of difficulty are used for determine Effective to Difficulty (ETD) value. ETD is used to determine which proactive action that company should implement first. ETD is calculated using the House of Risk (HOR) 2 matrix. The result of House of Risk (HOR) 2 is shown in Table 13. Based on the table, it is known ETD value of each proactive action and its ranking. The greater the ETD value of the proactive action means that the mitigation action is very effective in reducing or mitigating the risk agent [9]. The prioritized proactive action is shown in Table 14 below.

The proactive action that shown in Table 14 above will be recommended to XYZ in hope that it can help prevent or reduce risk agents so as to minimize the impact of risks that have the potential to interrupt the company's supply chain activity.

There are 11 supply chain risk mitigation actions that are prioritized to be implemented in XYZ, the first is make a contract with related parties (PA2), the second is direct controlling to the workers (PA5), the third is purchasing a generator (PA3), the fourth is addition working hours (PA7), the fifth is make a minimum order time rule (PA9), the sixth is hold a training for the workers (PA4), the seventh is create a routine schedule for maintenance (PA11), the eighth is give a warning to the supplier (PA1), the ninth is maintain customer relationship (PA8), the tenth is create an efficient delivery schedule (PA10), and the eleventh is labor recruitment (PA6).

Table 13. House of Risk (HOR) 2.

\begin{tabular}{|c|c|c|c|c|c|c|c|c|}
\hline \multirow{2}{*}{$\begin{array}{c}\text { To be Treated Risk Agent } \\
\text { (Aj) }\end{array}$} & \multicolumn{7}{|c|}{ Proactive Action } & $\begin{array}{c}\text { Aggregate Risk } \\
\text { Potentials (ARP) }\end{array}$ \\
\hline & PA1 & PA2 & PA3 & PA4 & PA5 & $\ldots$ & PA11 & 1279.5 \\
\hline A9 & 3 & 9 & & & & & & 1181.1 \\
\hline A14 & & & 9 & & & & & 785.2 \\
\hline A13 & & & & 9 & 9 & & & 743.9 \\
\hline A15 & & & & & & & & 735.5 \\
\hline A1 & & & & & & & & 679.1 \\
\hline A5 & & & & & & & & 624.8 \\
\hline A10 & & & & & & & 9 & 589.1 \\
\hline A7 & & 9 & & & & & & \\
\hline Total Effectiveness & 3838.5 & 16817.2 & 10629.7 & 7066.4 & 7066.4 & $\ldots$ & 5623.1 & \\
\hline Degree of Difficulty & 3.8 & 3.3 & 4.6 & 4 & 3 & $\ldots$ & 3.8 & \\
\hline Effectiveness to Difficulty & 1005.3 & 5138.6 & 2292.7 & 1766.6 & 2355.5 & $\ldots$ & 1472.7 & \\
\hline Rank of Priority & 8 & 1 & 3 & 6 & 2 & $\ldots$ & 7 & \\
\hline
\end{tabular}


Table 14. Prioritized proactive action.

\begin{tabular}{|l|l|}
\hline Code & \multicolumn{1}{|c|}{ Proactive Action } \\
\hline PA2 & Make a contract with related parties \\
\hline PA5 & Direct controlling to the workers \\
\hline PA3 & Purchasing a generator \\
\hline PA7 & Addition working hours \\
\hline PA9 & Make a minimum order time rule \\
\hline PA4 & Hold a training for the workers \\
\hline PA11 & $\begin{array}{l}\text { Create a routine schedule for mainte- } \\
\text { nance }\end{array}$ \\
\hline PA1 & Give a warning to the supplier \\
\hline PA8 & Maintain customer relationship \\
\hline PA10 & Create an efficient delivery schedule \\
\hline PA6 & Labor recruitment \\
\hline
\end{tabular}

\section{CONCLUSION}

There are 20 risk events that have the potential to interrupt supply chain activities in XYZ and 16 risk agents that cause risk in XYZ from the SCOR model which consists of five core processes. There are 8 supply chain risk agents that are prioritized in $\mathrm{XYZ}$, there are lack of accuracy from the supplier (A9), power outage from national electricity company (A14), lack of accuracy when making the product (A13), lack of human resources (A15), sudden change in demand by customer (A1), lack of maintenance (A10), and lack of coordination with soybean suppliers (A7). There are 11 supply chain risk mitigation actions that are prioritized to be implemented in XYZ that are make a contract with related parties (PA2), direct controlling to the workers (PA5), purchasing a generator (PA3), addition working hours (PA7), make a minimum order time rule (PA9), hold a training for the workers (PA4), create a routine schedule for maintenance (PA11), give a warning to the supplier (PA1), maintain customer relationship (PA8), create an efficient delivery schedule (PA10), and labor recruitment (PA6).

\section{REFERENCES}

[1] Pujawan I N and Mahendrawathi E 2017 Supply Chain Management ed 3 (Yogyakarta: Andi Publisher)

[2] Yan W, He J, Trappey A J C 2019 Risk-aware supply chain intelligence: AI-enabled supply chain and logistics management considering risk mitigation Advanced Engineering Informatics 42 1-2

[3] Kulsum, Muharni Y, Pratiwi A S 2019 Comparison of job shop production scheduling by using the non- delay method and the Heijunka method at PT XYZ IOP Conf. Ser. Mater. Sci. Eng. 673 1-5

[4] Sreedevi R and Saranga H 2017 Uncertainty and supply chain risk: The moderating role of supply chain flexibility in risk mitigation Int. J. Prod. Econ. 193 332-342

[5] Kırılmaz O and Erol S 2017 A proactive approach to supply chain risk management: Shifting orders among suppliers to mitigate the supply side risks J. Purch. Supply Manag. 23 54-65

[6] Ghadge A, Dani S, Ojha R, and Caldwell N 2017 Using risk sharing contracts for supply chain risk mitigation: A buyer-supplier power and dependence perspective Comput. Ind. Eng. 103 262-270

[7] El Baz J and Ruel S 2021 Can supply chain risk management practices mitigate the disruption impacts on supply chains' resilience and robustness? Evidence from an empirical survey in a COVID-19 outbreak era Int. J. Prod. Econ. 233107972

[8] Chowdhury M M H and Quaddus M A 2021 Supply chain sustainability practices and governance for mitigating sustainability risk and improving market performance: A Dynamic capability perspective J. Clean. Prod. 278123521

[9] Khalilabadi S M G, Zegordi S H, Nikbakhsh E 2020 A multi-stage stochastic programming approach for supply chain risk mitigation via product substitution Comput. Ind. Eng. 149106786

[10] Rajagopal V, Venkatesan S P, and Goh M 2017 Decision-making models for supply chain risk mitigation: A review Comput. Ind. Eng. 113 646-682

[11] Aini Q, Utami D P, and Qomariah T J 2019 Applying house of risk analysis for supply chain risk mitigation (case study) 2019 7th Int. Conf. Cyber IT Serv. Manag. CITSM 2019

[12] Santillán-Saldivar J, Cimprich A, Shaikh N, Laratte B, Young S B, and Sonnemann G 2021 How recycling mitigates supply risks of critical raw materials: Extension of the geopolitical supply risk methodology applied to information and communication technologies in the European Union Resour. Conserv. Recycl. 164 1-8

[13] Trenggonowati D L and Pertiwi N A 2017 Analysis of risk causes and risk mitigation using the house of risk method at the procurement division of PT XYZ J. Ind. Serv. 3 1-7

[14] Yang P, Tang J, and Yan C 2012 A Case Study of global supply chain risk management Proc. 2012 24th Chinese Control Decis. Conf. CCDC 2012 1996-2000

[15] Carbonara N, Costantino N, Pellegrino R 2014 Mitigating supply chain risk: A real options approach IEEE Int. Conf. Ind. Eng. Eng. Manag. 892-896 
[16] Trenggonowati D L, Ulfah M, Arina F, and Lutfiah C 2020 Analysis and strategy of supply chain risk mitigation using fuzzy failure mode and effect analysis (fuzzy FMEA) and fuzzy analytical hierarchy process (fuzzy AHP) IOP Conf. Ser. Mater. Sci. Eng. 909 1-11

[17] Ridwan A, Ferdinant P F, and Wahyuni E 2020 Design of supply chain risk mitigation for pallet and dunnage products using the house of risk method Tek. J. Sains dan Teknol. 16 35-44

[18] Pujawan I N and Geraldin L H 2009 House of risk: A model for proactive supply chain risk management Bus. Process Manag. J. 15 953-967

[19] Chan S and Larsen G N 2010 A framework for supplier-supply chain risk management: Tradespace factors to achieve risk reduction - Return on investment 2010 IEEE Int. Conf. Technol. Homel. Secur. HST 2010 29-34

[20] Wang D and Yang Z 2007 Risk management of global supply chain Proc. IEEE Int. Conf. Autom. Logist. ICAL 2007 1150-1155 